\title{
Carbon cycling and bacterial carbon sources in pristine and impacted Mediterranean seagrass sediments
}

\author{
M. Holmer ${ }^{1, *}$, C. M. Duarte ${ }^{2}$, H. T. S. Boschker ${ }^{3}$, C. Barrón ${ }^{2}$ \\ ${ }^{1}$ Institute of Biology, University of Southern Denmark, Campusvej 55, 5230 Odense M, Denmark \\ ${ }^{2}$ IMEDEA (CSIC-UiB), Grupo de Oceanografia Interdisciplinar, Instituto Mediterráneo de Estudios Avanzados, \\ C/Miquel Marqués 21, 07190 Esporles (Islas Baleares), Spain \\ ${ }^{3}$ Netherlands Institute of Ecology (NIOO-KNAW), PO Box 140, 4400 AC Yerseke, The Netherlands
}

\begin{abstract}
Stable carbon-isotope ratios of bacterial biomarkers were studied in Mediterranean seagrass meadows and macroalgae communities to identify the sources of organic carbon used by the sediment bacteria. Bacteria $\delta^{13} \mathrm{C}$ ratios in pristine sediments vegetated by the seagrass Posidonia oceanica were either similar to the seagrass signal or slightly enriched, suggesting that seagrass detritus was of major importance as a bacterial carbon source. There was a shift in bacterial carbon sources in anthropogenic impacted $P$. oceanica meadows towards seston and macroalgae. The net primary productivity was reduced in these meadows, whereas the rates of mineralization as measured by sulfate reduction rates were enhanced in the sediments. This effect on mineralization was probably due to the input of less refractory organic matter compared to seagrass detritus, which enhances the bacterial decomposition of organic matter. In the fast growing seagrass Cymodocea nodosa meadow, the bacterial carbon sources consisted of a mixture of seagrass detritus and seston, and the mineralization rates were much higher compared to the $P$. oceanica meadows, indicating that these carbon sources were more labile and easily decomposed by the bacteria. A similar pattern was found in the macroalgae bed with Caulerpa prolifera, where the rates of mineralization were high, similar to findings in organic impacted fish farm sediments. Here C. prolifera detritus was the most important carbon source and accounted for an increase in sediment organic content. The possible impacts of a shift in bacterial carbon sources due to nutrient loading are discussed in relation to the performance of $P$. oceanica in carbonate sediments.
\end{abstract}

KEY WORDS: Seagrass $\cdot$ Sediments $\cdot$ Carbon cycling $\cdot \delta^{13} \mathrm{C} \cdot$ Bacterial substrates $\cdot$ Sulfate reduction

\section{INTRODUCTION}

Stable carbon-isotope compositions offer a convenient tool for studying the sources of organic carbon in ecosystems and the fate of organic carbon in food webs (Fry \& Sherr 1984). The stable carbon-isotope composition of macroscopic organisms can be readily established, whereas that of microbial components cannot be easily separated from similar sized organisms or detritus contained in the bulk pool of particulate organic matter. However, recent methodological developments have made it possible to study carbon sources used by bacteria even within the diverse and complex conditions encountered in marine sediments (Boschker et al. 1998, 1999).

Coastal sediments contain a broad spectrum of organic matter sources of terrestrial and marine origin (Hedges 1992). Seagrass meadows are important components of coastal benthic ecosystems, which channel a large part of their production through the detrital food chain due to a generally low grazing pressure (Duarte \& Cebrián 1996, Hemminga \& Duarte 2000). Seagrasses also supply organic matter directly to benthic bacteria through root exudates (Blaabjerg \& Finster 1998, Holmer et al. 2001) and may support productive epiphytic communities, which also contribute 
organic matter to the system (Hemminga \& Duarte 2000). Moreover, seagrass meadows trap particles and prevent resuspension due to their effect on the physical settings (Gacia \& Duarte 2001, Agawin \& Duarte 2002), resulting in an important input of sestonic material to seagrass sediments (Gacia et al. 2002). The relative use of all of these sources of organic matter potentially available to the benthic bacterial community in seagrass meadows depends on multiple factors, such as the lability of the organic matter, the oxygen exposure time and the availability of electron acceptors (Hartnett et al. 1998, Kristensen \& Holmer 2001). The contribution of seagrass-derived organic matter relative to alternative sources as a substrate of organic matter to bacteria remains largely unresolved.

Recent developments in the analysis of compoundspecific stable carbon-isotope composition have allowed the organic sources for bacterial growth in seagrass meadows to be resolved (Boschker et al. 2000, Holmer et al. 2001). Analyses of isotopic ratios from bacteria specific polar lipid-derived fatty acids allow the stable carbon-isotope composition of bacteria to be resolved (Boschker \& Middelburg 2002). The isotopic composition of the bacteria reflects the $\delta^{13} \mathrm{C}$ ratios of the carbon sources utilized by the bacteria, which can be compared to the characteristic $\delta^{13} \mathrm{C}$ ratios of different sources of organic matter to infer their relative importance as carbon sources for the bacteria. Such studies have shown diverging results in seagrass sediments, as the carbon sources differ among seagrass species (Holmer et al. 2001) and between locations (Boschker et al. 2000). In most seagrass beds studied so far, the bacteria appear to use several carbon sources, and seagrass detritus only plays a partial role. In 4 European Zostera marina meadows, bacterial ratios were in most cases similar to those for benthic macroalgae and benthic diatoms found at the locations, and short-term laboratory incubations with $Z$. marina were not able to provide evidence of release of organic carbon from the roots, suggesting that root exudation by eelgrass was of minor importance for the bacterial communities (Boschker et al. 2000). Several of the sites used in these studies were quite eutrophic, due to high nutrient loading by run-off from agricultural land (Boschker et al. 2000), where contributions by primary producers other than seagrass may be high. Indeed, a study conducted in 2 oligotrophic tropical seagrass beds showed a much closer coupling between the seagrass isotopic signal and that of bacteria (Holmer et al. 2001). A splitchamber experiment revealed large release of photosynthetic compounds from the roots in these tropical seagrass beds, sufficient to support the bacterial activity measured in the sediments (Holmer et al. 2001).

Such shifts in organic carbon sources from seagrass detritus to more labile sources may have a major influ- ence on the sediment environment and in turn affect conditions for seagrass growth. An increased supply of labile, non-seagrass organic matter along eutrophication gradients may lead to enhanced microbial activity in the sediments (Harvey et al. 1995, Hansen \& Kristensen 1998). Enhanced bacterial mineralization increases the nutrient supply for root uptake, and therefore stimulates seagrass growth in nutrient-limited meadows. However, increased mineralization in marine sediments often leads to stimulation of sulfate reduction rates (SRR) (Holmer \& Kristensen 1996), which may create anoxic conditions in the rhizosphere and lead to the accumulation of sulfides. This may have major impact on the survival of seagrasses (Terrados et al. 1999, Holmer \& Bondgaard 2001), particularly for seagrasses adapted to growth in oxidized sediments under oligotrophic conditions, such as the slow-growing seagrass Posidonia oceanica (Bethoux \& Copin-Móntegu 1986). P. oceanica is widely distributed in the Mediterranean but is declining at many locations in this area (Marbá et al. 1996, 2002). Increased organic inputs have been identified to be a key factor in this decline (Delgado et al. 1997, Ruiz et al. 2001, Marbá et al. 2002, Holmer et al. 2003a).

The aim of the present study was to examine the carbon sources in seagrass ecosystems in the Mediterranean, ranging from pristine ecosystems to those impacted by enhanced nutrient and organic inputs, and to assess if there is a shift in bacterial carbon sources along this gradient. The stable carbon-isotope composition of the sediment bacteria was examined in seagrass meadows (Posidonia oceanica and Cymodocea nodosa) and in a community dominated by a macroalgae (Caulerpa prolifera) growing in a eutrophic embayment. We examine the relationship between the carbon sources used by bacteria with inputs of organic carbon through sedimentation and primary production.

\section{MATERIALS AND METHODS}

The study was conducted at Mallorca Island and the adjacent Cabrera Island National Park $\left(39^{\circ} 9^{\prime} \mathrm{N}\right.$, $\left.2^{\circ} 56^{\prime} \mathrm{E}\right)$, which is a protected marine area. Five study sites with benthic vegetation (Posidonia oceanica, Cymodocea nodosa or Caulerpa prolifera) encompassing a range of pristine to impacted locations were selected (Table 1). Two of the sites were on Mallorca: one (Magalluf) was located in an exposed area, whereas the other was in a sheltered bay (Porto Colom) highly impacted by nutrient and organic inputs from the surrounding town and boating activity as well as a fish farm. Two additional sites (Es Port and Sa Paret) were located in an enclosed bay at Cabrera Island, where one of the sites (Sa Paret) is impacted by organic inputs 
Table 1. Description of study sites showing the dominant types of vegetation (seagrasses and macroalgae) found at the site, the sampling depth, the physical conditions at the location and the anthropogenic pressures

\begin{tabular}{|llccc|}
\hline Location & \multicolumn{1}{c}{$\begin{array}{c}\text { Vegetation } \\
\text { type }\end{array}$} & $\begin{array}{c}\text { Water } \\
\text { depth }(\mathrm{m})\end{array}$ & $\begin{array}{c}\text { Physical } \\
\text { conditions }\end{array}$ & $\begin{array}{c}\text { Anthropogenic } \\
\text { pressures }\end{array}$ \\
\hline Magalluf & $\begin{array}{l}\text { Posidonia oceanica } \\
\text { Sta. Maria }\end{array}$ & 4 & Exposed & None \\
Sa Paret & $\begin{array}{l}\text { Posidonia oceanica } \\
\text { Ptilophora mediterranean } \\
\text { Porto Colom }\end{array}$ & 13 & Exposed & None \\
& $\begin{array}{l}\text { Posidonia oceanica, } \\
\text { Caulerpa prolifera }\end{array}$ & 5 & Sheltered & Nutrient loaded \\
Es Port & Cymodocea nodosa & 3 & Sheltered & None \\
\hline
\end{tabular}

Rates of sedimentation were measured by deploying benthic sediment traps for $24 \mathrm{~h}$. The traps consisted of $20 \mathrm{ml}$ cylindrical glass centrifugation tubes with an aspect ratio of 5 (16 mm diameter), in order to prevent internal resuspension. Five replicated traps were deployed at each site, and the contents of each sediment trap were collected on a combusted, preweighed Whatman GF/F filter, and its dry weight was obtained after drying at $60^{\circ} \mathrm{C}$ to constant weight. Sedimentation rates were estimated according to Blomqvist \& Håkanson (1981) and

(Marbá et al. 2002); the fifth site (Sta. Maria) was situated in a more exposed, very pristine section of the bay (Marbá et al. 2002). The study was conducted in May and June 2001, when the water temperature was $18^{\circ} \mathrm{C}$ and salinity was stable at \pm 38 PSU. Sediments and seagrasses were sampled at water depths between 2 and $17 \mathrm{~m}$, well above the local $35 \mathrm{~m}$ depth limit of the plants, which are therefore not expected to be stressed by low light conditions at the sampling sites.

The community metabolism of the Posidonia oceanica meadow, Caulerpa prolifera bed, Cymodocea nodosa meadow and the bare sediments at the 5 sampling sites, was studied using in situ benthic chambers (3 or 4 replicates). These chambers consisted of 2 parts, a PVC cylinder and a polyethylene plastic bag with a sampling port. The chambers were initially sampled for dissolved oxygen concentrations, just before sunset and after sunrise, using $50 \mathrm{ml}$ acid-washed syringes in order to estimate the gross primary production (GPP), the net community production (NCP) and the community respiration (R) from oxygen evolution. The dissolved oxygen concentrations were determined using the Winkler method with a Mettler DL21 titrator. R was estimated from the difference of oxygen concentration in the incubations before sunset and after sunrise, corrected for $24 \mathrm{~h}$. NCP was calculated from the changes in oxygen concentration during a full day and GPP was estimated by the sum of NCP and R. The volume of each chamber was estimated by injecting a concentrated phosphate solution at the end of the experiment. After mixing for $5 \mathrm{~min}$, water samples for phosphate analysis were collected and kept frozen for spectrophotometric determination (Hansen \& Koroleff 1999). The volume of each chamber was estimated by the difference in phosphate concentration from the concentrated solution added and the water sample collected and ranged from 2 to 121 . The seagrass and macroalgal photosynthetic material was harvested at the end of the experiment, rinsed and dried at $60^{\circ} \mathrm{C}$ to estimate the photosynthetic biomass.
Hargrave \& Burns (1979) as described in detail in Gacia et al. (1999) and Holmer et al. (2002). The trap material was analyzed for stable isotopic composition as described below. Samples of the benthic vegetation (separated into leaves and roots and rhizomes for seagrasses) present at each location were collected for analysis of stable isotopic composition and nutrient contents. A minimum of 10 seagrass shoots were collected at each site and epiphytes were removed manually. The samples were rinsed in seawater and frozen immediately after collection. After freeze drying, the plant material was homogenized and 1 analysis was performed on each homogenate. Sediment cores (2.6 and $4.3 \mathrm{~cm}$ inner diameter) were collected by SCUBA divers inside seagrass meadows and in adjacent bare sediments, if possible without cutting the roots. These cores were used to analyze stable isotopic composition of sediments and bacteria, SRR and sediment characteristics.

The upper $5 \mathrm{~cm}$ of the sediment cores was transferred to a beaker and frozen. Sediment and plant materials were freeze-dried for $24 \mathrm{~h}$ before further processing, and were then analyzed for silt content (sediment only), particulate organic carbon (POC) content, total nitrogen content, and stable isotope ratios of organic carbon (Nieuwenhuize et al. 1994, Middelburg \& Nieuwenhuize 1998). Briefly, carbon and nitrogen contents were determined using a Carlo-Erba NA $1500 \mathrm{CN}$ analyzer following an in situ $\mathrm{HCl}$ acidification procedure, and carbon isotopes were obtained on a Fisons NA1500 elemental analyzer coupled on-line to a Finnigan Delta S isotoperatio mass spectrometer. Phospholipid derived fatty acids (PLFA) were extracted from the sediments and analyzed as in Boschker et al. (1999) to determine the isotopic composition of sediment bacteria. In short, lipids were extracted in chloroform-methanol-water using a modified Bligh and Dyer method (Findlay et al. 1989) and fractionated on silicic acid into different polarity classes. The most polar fraction containing the PLFA was derivatized by mild methanolysis to yield fatty acid methyl esters (FAME). Carbon isotopic composition of individual 
FAME was determined using a gas-chromatographcombustion-interface isotope-ratio mass spectrometer (GC-c-IRMS); a HP G1530 GC (Hewlett Packard) connected to Delta-Plus IRMS via a type III combustion interface from Thermo Finnigan. Internal (12:0 and 19:0) and external FAME and alkane reference mixtures were used to check the accuracy of the isotopic ratios as determined by the GC-C-IRMS. Stable carbon-isotope ratios for individual PLFA were calculated from FAME data by correcting for the 1 carbon atom in the methyl group that was added during derivatization. The weightaveraged isotopic ratios of i15:0 and a15:0 were used to indicate bacterial $\delta^{13} \mathrm{C}$ ratios after correction for isotopic fractionation in fatty acids (5.6\%o, Boschker et al. 1999). The poly-unsaturated PLFA 20:5 03 was used as a biomarker for benthic microalgae, primarily diatoms (Boschker et al. 2000). Stable carbon-isotopes are expressed in the delta notation relative to Vienna PDB.

Sulfate reduction rates. Three sediment cores (2.6 cm inner diameter) were injected to measure SRR within $1 \mathrm{~h}$ of collection with $2 \mu \mathrm{ll}^{35} \mathrm{SO}_{4}( \pm 70 \mathrm{kBq})$ at $1 \mathrm{~cm}$ intervals and incubated for $2 \mathrm{~h}$ in darkness at in situ temperature. The incubation was terminated by sectioning the cores into $2 \mathrm{~cm}$ intervals down to $10 \mathrm{~cm}$ and fixing in $1 \mathrm{M}$ zinc acetate and freezing immediately. SRR were obtained by the 1-step distillation method which includes acid volatile sulfides and chromium reducible sulfur (including pyrite, Fossing \& Jørgensen, 1989). Radioactivity was counted on a Packard TriCarb 2000 scintillation counter and sulfide concentrations were determined spectrophotometrically according to Cline (1969). Sediment characteristics. Sediment density was obtained by weight of a known volume and the water content was obtained after drying overnight at $105^{\circ} \mathrm{C}$. Porosity was calculated from sediment density and water content.

\section{RESULTS}

\section{Stable carbon-isotope in seagrass meadows}

Stable carbon-isotope ratios of Posidonia oceanica leaves were very similar among the examined sites and ranged from -12.5 to $-14.7 \%$, whereas there was a larger variability in the ratios of the root material (-12.1 to $-16.2 \%$, Table 2). P. oceanica roots and shoots had similar isotopic ratios at the impacted sites (Sa Paret and Porto Colom), whereas the roots were more depleted compared to the shoots at the pristine sites. The macroalgae Ptilophora mediterranea found at Sa Paret was much depleted in ${ }^{13} \mathrm{C}$ $(-34.2 \%$ ) compared to seagrass material, whereas the macroalgae Caulerpa prolifera found in Porto Colom showed a carbon isotopic signal $(-13.9 \%)$ similar to the seagrass. The isotope ratios of the material collected in the sedimentation traps showed more depleted values in the Cabrera Island National Park $(-20.1$ to $-22.6 \%$ ), where they had a signal close to that characteristic of Mediterranean phytoplankton (Faganeli et al. 1994, Dauby et al. 1995), when compared to the sites around Mallorca Island for which the ratios were closer to those of the macrophytes $(-16.0$ to $-17.9 \%$, Table 3$)$. The sediments were generally more depleted in ${ }^{13} \mathrm{C}$ than the associated seagrasses but less depleted than the material collected in the sediment traps, and the sediments collected in the $P$. oceanica meadows were more depleted in ${ }^{13} \mathrm{C}$ $(-15.9$ to $-19.7 \%)$ than sediments in Cymodocea nodosa $(-14.8 \%$ ) and C. prolifera $(-15.2 \%$, Table 4$)$ stands.

At the pristine Posidonia oceanica sites, bacterial isotope ratios were either similar to the seagrasses or slightly enriched, whereas bacterial isotope ratios at

Table 2. Plant characteristics. Above-ground biomass $(n=3, \pm \mathrm{SE})$ and plant nutrient content (OC: organic carbon; ON: organic nitrogen; DW: dry weight) and $\delta^{13} \mathrm{C}$ for the seagrasses (leaf and root material) and macroalgae are given $(\mathrm{n}=1)$. C:N of the plant material is given as molar ratio

\begin{tabular}{|c|c|c|c|c|c|c|}
\hline Location & Plant & $\begin{array}{l}\text { Biomass } \\
\left(\mathrm{g} \mathrm{m}^{-2}\right)\end{array}$ & $\begin{array}{c}\mathrm{OC} \\
(\% \mathrm{DW})\end{array}$ & $\begin{array}{c}\text { ON } \\
(\% \mathrm{DW})\end{array}$ & $\begin{array}{l}\text { C:N } \\
\text { molar }\end{array}$ & $\begin{array}{l}\delta^{13} \mathrm{C} \\
(\%)\end{array}$ \\
\hline Magalluf & $\begin{array}{c}\text { Posidonia oceanica } \\
\text { Roots }\end{array}$ & $\begin{array}{c}490 \pm 80 \\
-\end{array}$ & $\begin{array}{l}35.0 \\
37.6\end{array}$ & $\begin{array}{l}1.33 \\
0.36\end{array}$ & $\begin{array}{r}26.2 \\
103.2\end{array}$ & $\begin{array}{l}-12.8 \\
-13.5\end{array}$ \\
\hline Sta. Maria & $\begin{array}{c}\text { Posidonia oceanica } \\
\text { Roots }\end{array}$ & $\begin{array}{c}612 \pm 133 \\
-\end{array}$ & $\begin{array}{l}30.8 \\
34.6\end{array}$ & $\begin{array}{l}0.80 \\
0.43\end{array}$ & $\begin{array}{l}38.5 \\
80.2\end{array}$ & $\begin{array}{l}-14.7 \\
-16.2\end{array}$ \\
\hline Sa Paret & $\begin{array}{c}\text { Posidonia oceanica } \\
\text { Roots } \\
\text { Ptilophora mediterranean }\end{array}$ & $\begin{array}{c}471 \pm 129 \\
- \\
\text { nd }\end{array}$ & $\begin{array}{l}33.1 \\
28.9 \\
31.5\end{array}$ & $\begin{array}{l}0.87 \\
0.41 \\
2.2\end{array}$ & $\begin{array}{l}38.1 \\
69.9 \\
14.1\end{array}$ & $\begin{array}{l}-13.5 \\
-13.3 \\
-34.2\end{array}$ \\
\hline Porto Colom & $\begin{array}{l}\text { Posidonia oceanica } \\
\text { Roots } \\
\text { Caulerpa prolifera }\end{array}$ & $\begin{array}{c}527 \pm 145 \\
- \\
226 \pm 24\end{array}$ & $\begin{array}{l}36.5 \\
25.8 \\
23.2\end{array}$ & $\begin{array}{l}1.94 \\
1.83 \\
2.2\end{array}$ & $\begin{array}{l}18.7 \\
14.1 \\
10.5\end{array}$ & $\begin{array}{l}-12.5 \\
-12.1 \\
-13.9\end{array}$ \\
\hline Es Port & $\begin{array}{c}\text { Cymodocea nodosa } \\
\text { Roots }\end{array}$ & $\begin{array}{c}\text { nd } \\
-\end{array}$ & $\begin{array}{l}31.6 \\
30.0\end{array}$ & $\begin{array}{l}1.50 \\
0.59\end{array}$ & $\begin{array}{l}21.1 \\
51.2\end{array}$ & $\begin{array}{l}-9.0 \\
-7.9\end{array}$ \\
\hline
\end{tabular}


Table 3. Sedimentation rates, particulate organic content (POC: particulate organic carbon; PON: particulate organic nitrogen), C:N ratio and $\delta^{13} \mathrm{C}$ of the sedimentation material measured at the 5 study sites. Values are given as average of 2 replicates ( \pm range).

\begin{tabular}{|lccccc|}
\hline Location & $\begin{array}{c}\text { Sedimentation } \\
\left(\mathrm{g} \mathrm{DW} \mathrm{m} \mathrm{m}^{-2} \mathrm{~d}^{-1}\right)\end{array}$ & $\begin{array}{c}\text { POC } \\
(\% \mathrm{DW})\end{array}$ & $\begin{array}{c}\text { PON } \\
(\% \mathrm{DW})\end{array}$ & $\begin{array}{c}\mathrm{C}: \mathrm{N} \\
\text { molar }\end{array}$ & $\begin{array}{c}\delta^{13} \mathrm{C} \\
(\% \circ)\end{array}$ \\
\hline Magalluf & $5.13 \pm 0$ & $9.3 \pm 0.8$ & $1.01 \pm 0.22$ & $11.1 \pm 1.6$ & $-17.9 \pm 0.1$ \\
Sta. Maria & $3.13 \pm 0.02$ & $1.0 \pm 0.2$ & $0.09 \pm 0.03$ & $13.3 \pm 1.9$ & $-22.6 \pm 0.8$ \\
Sa Paret & $6.36 \pm 0.47$ & $4.4 \pm 0.4$ & $0.45 \pm 0.03$ & $11.5 \pm 0.3$ & $-21.6 \pm 1.0$ \\
Porto Colom & $19.96 \pm 0.64$ & $3.1 \pm 0.5$ & $0.21 \pm 0.05$ & $17.5 \pm 1.1$ & $-16.0 \pm 0.6$ \\
Es Port & $6.36 \pm 0.47$ & $1.6 \pm 0.1$ & $0.13 \pm 0.01$ & $14.4 \pm 1.0$ & $-20.1 \pm 0.9$ \\
\hline
\end{tabular}

\section{Plant, sedimentation and sediment characteristics}

The above-ground biomass did not vary significantly among the Posidonia oceanica study sites, and was about 2 times higher than the Caulerpa prolifera biomass (Table 2). The nutrient contents were highest in the leaves, resulting in lower $C: N$ ratios (18.7 to 38.5) compared to roots (69.9 to 103.2) except for Porto Colom, the impacted sites showed values between those of the seagrasses and the sediment (Fig. 1A). At the bare sites adjacent to seagrass stands, all bacterial ratios differed from the sediment ratios and were instead close to the seagrass ratios (Fig. 1B). For Cymodocea nodosa, bacterial ratios were similar to the sediment ratio, which was depleted compared to the seagrasses. The sediment traps showed even more depleted ratios (Fig. 2). In addition, the bacterial ratios at the adjacent bare sites showed an isotopic signal similar to the sediment organic matter. The difference between bacteria and the examined substrates was much less for the Caulerpa prolifera site. Here the bacteria isotopic signature closely resembled the macroalgae, and the sediments and the traps were only slightly depleted in comparison (Fig. 2). The isotopic ratios of the benthic microalgae marker (20:5 03 ) showed no correlation with the bacterial marker ratios (Fig. 3).

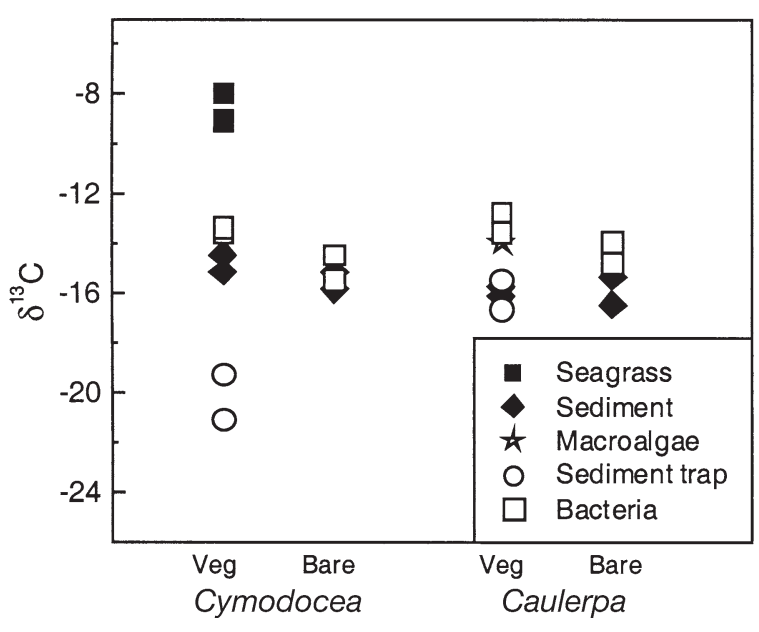

Fig. 1. Stable carbon-isotope ratios of sediment traps, seagrasses (average leaf and root) and benthic macroalgae, sediment and bacteria in vegetated and bare sites for Cymodocea nodosa and Caulerpa prolifera communities

Table 4. Sediment characteristics at vegetated and bare sites (Veg/bare) at the 5 study sites given as mean (n $=2, \pm$ range). Percent silt (\%silt), particulate organic carbon (POC) and nitrogen (PON), molar C:N and the $\delta^{13} \mathrm{C}$ on the sediment organic matter $\left(\delta^{13} \mathrm{C}\right)$ are given. The accumulation of total reducible sulfur (TRS) was measured on separate cores $(n=3, \pm$ SEM)

\begin{tabular}{|lccccccc}
\hline Location & Veg/bare & $\begin{array}{c}\% \text { silt } \\
<63 \mu \mathrm{m}\end{array}$ & $\begin{array}{c}\text { POC } \\
(\% \mathrm{DW})\end{array}$ & $\begin{array}{c}\text { PON } \\
(\% \mathrm{DW})\end{array}$ & $\begin{array}{c}\mathrm{C}: \mathrm{N} \\
\text { molar }\end{array}$ & $\begin{array}{c}\delta^{13} \mathrm{C} \\
(\%)\end{array}$ & $\begin{array}{c}\text { TRS } \\
\left(\mathrm{mol} \mathrm{m} \mathrm{m}^{-2}\right)\end{array}$ \\
\hline Magalluf & Posidonia oceanica & $3.1 \pm 0.4$ & $0.26 \pm 0.04$ & $0.031 \pm 0.001$ & $9.6 \pm 1.0$ & $-18.7 \pm 0.4$ & $0.19 \pm 0.09$ \\
& Bare & $1.4 \pm 0.1$ & $0.19 \pm 0$ & $0.030 \pm 0.002$ & $7.4 \pm 0.7$ & $-19.7 \pm 1.3$ & $0.12 \pm 0.02$ \\
Sta. Maria & Posidonia oceanica & $12.1 \pm 0.8$ & $0.41 \pm 0.03$ & $0.051 \pm 0.006$ & $9.6 \pm 1.4$ & $-17.8 \pm 0.1$ & $0.16 \pm 0.02$ \\
& Bare & $3.8 \pm 0.8$ & $0.85 \pm 0.62$ & $0.023 \pm 0$ & $42.5 \pm 31.1$ & $-17.7 \pm 0$ & $0.08 \pm 0.02$ \\
Sa Paret & Posidonia oceanica & $59.1 \pm 1.5$ & $3.77 \pm 1.04$ & $0.263 \pm 0.037$ & $16.5 \pm 2.4$ & $-16.5 \pm 0.2$ & $0.98 \pm 0.11$ \\
& Bare & $5.1 \pm 0.4$ & $0.21 \pm 0.03$ & $0.033 \pm 0.008$ & $7.7 \pm 0.8$ & $-17.6 \pm 0.6$ & $0.05 \pm 0.01$ \\
Porto Colom 1 & Posidonia oceanica & $22.4 \pm 0.1$ & $0.45 \pm 0.04$ & $0.031 \pm 0.003$ & $17.0 \pm 0.4$ & $-17.0 \pm 0.5$ & $3.82 \pm 0.85$ \\
& Bare & $7.9 \pm 1.0$ & $1.12 \pm 0.67$ & $0.059 \pm 0.030$ & $20.7 \pm 2.6$ & $-15.9 \pm 0.2$ & $1.96 \pm 0.34$ \\
Porto Colom 2 & Caulerpa prolifera & $53.3 \pm 2.6$ & $3.99 \pm 0.29$ & $0.336 \pm 0.010$ & $13.9 \pm 1.4$ & $-15.2 \pm 0$ & $1.65 \pm 0.33$ \\
& Bare & $63.5 \pm 2.5$ & $4.11 \pm 0.01$ & $0.362 \pm 0.010$ & $13.3 \pm 0.4$ & $-15.9 \pm 0.6$ & $2.18 \pm 0.20$ \\
Es Port & Cymodocea nodosa & $55.7 \pm 2.9$ & $2.84 \pm 0.20$ & $0.152 \pm 0.007$ & $21.8 \pm 0.6$ & $-14.8 \pm 0.4$ & $12.80 \pm 0.81$ \\
& Bare & $51.9 \pm 3.2$ & $2.85 \pm 0.29$ & $0.117 \pm 0.007$ & $28.3 \pm 1.1$ & $-15.5 \pm 0.4$ & $27.14 \pm 2.78$ \\
& & & & & & & \\
\hline
\end{tabular}



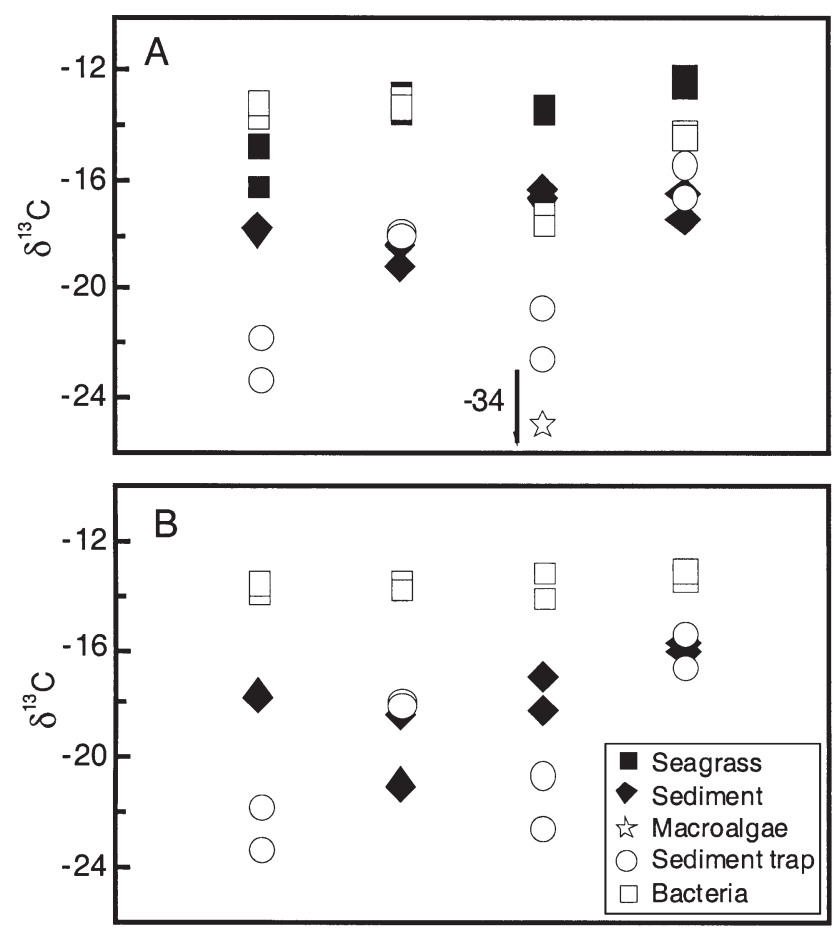

Sta. Maria Magalluf Sa Paret Porto Colom

Fig. 2. Stable carbon-isotope ratios of sediment traps, seagrasses (average leaf and root), benthic macroalgae, sediment and bacteria in (A) Posidonia oceanica meadows and (B) bare sites in connection to the meadows. Each source was analyzed twice, except for seagrasses where the symbols represent 1 leaf and 1 root sample

where the C:N ratio of the roots (14.1) was low due to a high nitrogen content compared to roots found at the other locations. The nitrogen content was also high in the macroalgae Ptilophora mediterranea and resulted in a low C:N ratio (14.1). C. prolifera and Cymodocea nodosa also showed high nitrogen contents and relatively low C:N ratios (10.5 and 21.1, respectively, Table 2).

Sedimentation rates varied by a factor of 6 between the lowest (Sta. Maria) and highest (Porto Colom) loading rates (Table 3). The organic content of the trap material was generally low $(<9.3 \%$ POC and $<1.01 \%$ $\mathrm{PON}$ ), and the $\mathrm{C}: \mathrm{N}$ ratios of the material collected ranged between 11.1 and 17.5. The sediments differed among study sites, with the bare sites having low organic contents $(0.19$ to $0.85 \%$ POC) compared to sediments within Posidonia oceanica meadows (0.26 to $3.77 \%$ POC, Table 4). Only the bare site (1.12\% POC) in Porto Colom was more enriched compared to the vegetated site $(0.45 \%$ POC). There was no difference between vegetated and bare sites for the Caulerpa prolifera and Cymodocea nodosa sediments, and the organic contents were higher (2.84 to $4.11 \%$ POC) compared to the $P$. oceanica sites. The C:N ratios of sedimentary organic matter also showed large difference, with relatively low values in vegetated $P$. oceanica sediments (9.6 to 17.0) compared to bare sites (7.4 to 42.5$)$ and the other benthic primary producers (13.9 to 21.8 ).

The total reducible sulfur (TRS) pools were either quite low at the pristine Posidonia oceanica sites $\left(<0.19 \mathrm{~mol} \mathrm{~m}^{-2}\right)$ or at least 5 times higher $(>0.98 \mathrm{~mol}$ $\mathrm{m}^{-2}$ ) at impacted sites (Table 4 ). The TRS pool was particularly high in the Cymodocea nodosa sediments (12.8 to $27.1 \mathrm{~mol} \mathrm{~m}^{-2}$ ).

\section{Community production and respiration}

The NCP of the Posidonia oceanica meadow was 3 to 5 times higher (Fig. 4) than Cymodocea nodosa and Caulerpa prolifera beds (Fig. 5). The most pristine $P$. oceanica meadow in Sta. Maria had the highest NCP, whereas the lowest was found at Sa Paret. R in the meadows was similar except for Porto Colom, where rates were $50 \%$ lower compared to the other sites. NCP was only measured at 2 bare sites, both of which were autotrophic but with a production only $1 / 10$ of that in the meadows. The anaerobic mineralization activity was assessed by measurements of SRR, as sulfate reduction has been shown to be an important mineralization process in these seagrass sediments, where the concentrations of other potential anaerobic electron acceptors such as nitrate and iron are low (Holmer et al. 2003). Sulfate reduction showed a large variation between sites (Fig. 4), with lowest rates in the pristine

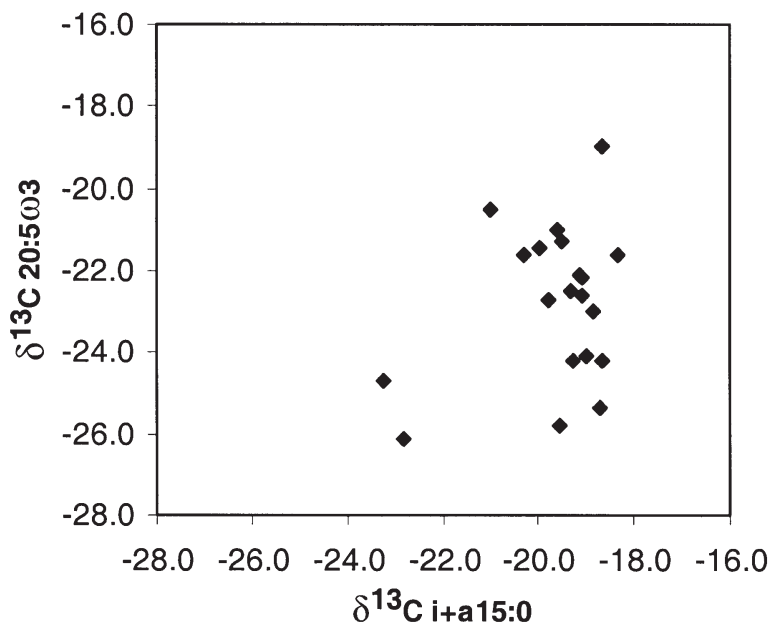

Fig. 3. Relationship between stable carbon-isotope ratios of bacterial (i+a15:0) and dominant algal (20:5 03$)$ phospholipid fatty acids (PLFA) in the sediment of all study sites. Actual PLFA data are shown and bacterial data were not corrected for the difference between PLFA and bacterial biomass 


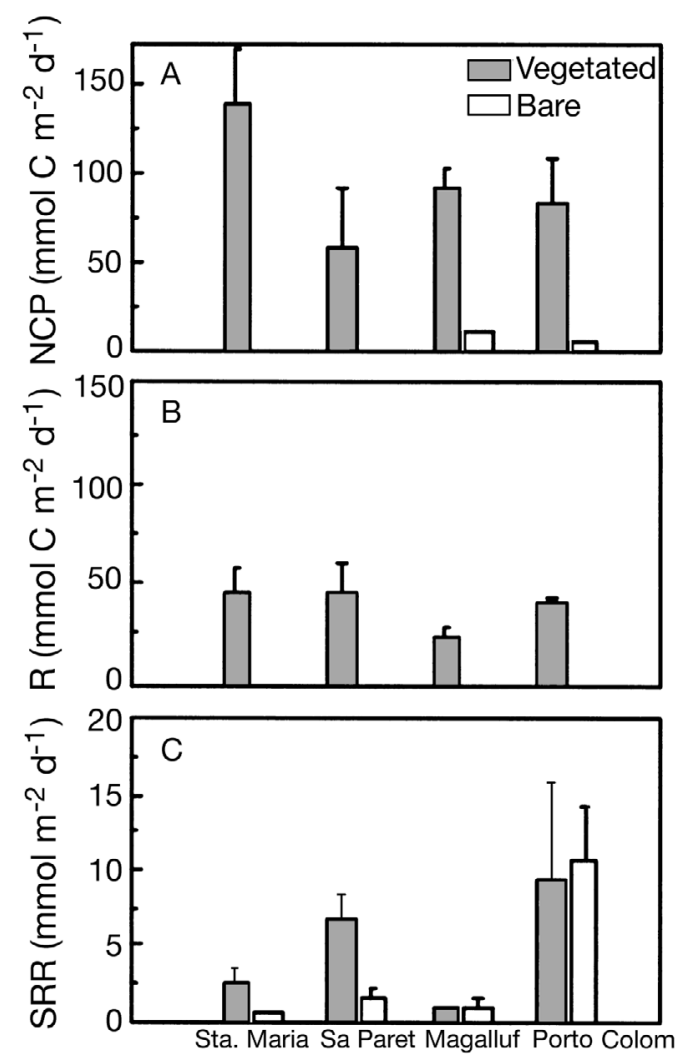

Fig. 4. (A) Net community production (NCP), (B) community respiration $(\mathrm{R})$ and $(\mathrm{C})$ depth integrated sulfate reduction rates (SRR) in vegetated and bare sites in Posidonia oceanica meadows. Bars represent mean of 3 replicates $( \pm$ SEM). NCP and respiration were only measured at bare sites in Magalluf and Porto Colom, and the respiration was below detection limit

P. oceanica meadows ( 0.7 to $\left.2.5 \mathrm{mmol} \mathrm{m} \mathrm{m}^{-2} \mathrm{~d}^{-1}\right)$. The rates at the impacted sites were up to 13 times higher (6.6 to $9.4 \mathrm{mmol} \mathrm{m}^{-2} \mathrm{~d}^{-1}$, Fig. 1). SRR at the bare sites were, in most cases, lower when compared to the vegetated sites, except for Porto Colom, where there was no difference between vegetated and bare sites. The rates were very high at the other sites, particularly in the C. prolifera sediments $\left(98 \mathrm{mmol} \mathrm{m}^{-2} \mathrm{~d}^{-1}\right.$, Fig. 5). Anaerobic respiration represented, on average, $23 \%$ of the aerobic respiration rates in the $P$. oceanica meadows, with the share of anaerobic respiration being highest at the impacted Porto Colom site $(46 \%)$ and lowest at the pristine Magalluf site (6\%).

\section{DISCUSSION}

The stable carbon-isotope signal of sediment bacteria, ranging from -12 to $-16 \%$, was remarkably similar across the broad range of sites and communities studied, except for somewhat lower values in Sa Paret. The stable carbon-isotope signal of sediment bacteria showed a narrower range than either one of their possible carbon sources, including seagrass ( -8 to $-16 \%$ ), material collected by the sediment traps $(-15$ to $-24 \%)$, sediment organic matter ( -16 to $-22 \%$ ) and macroalgae $(-14$ to $-34 \%)$. The stable carbon-isotope signal in sediment bacteria in Posidonia oceanica meadows was generally similar to the seagrass signal, indicative of preferential use of seagrass organic matter by bacteria. Only the stations impacted by anthropogenic inputs deviated from this pattern, where the signal was shifted towards other sources. This indicates that seagrass material contributes significantly to the bacterial carbon sources at the pristine sites, whereas other sources play a role at the anthropogenic sites. At the anthropogenic impacted site Sa Paret, large quantities of the red algae Ptilophora mediterranea were found within the seagrass meadow. This alga showed a highly depleted isotopic value consistent with the lower isotopic value of the bacteria at this site. Invasion of seagrass beds by thin-leafed macroalgae is a sign of nutrient enrichment (Valiela et al. 1997) as this type of macroalgae has a much faster growth rate and can compete with seagrasses at high nutrient concentra-
Fig. 5. Net community production $(\mathrm{NCP})$ at $(\mathrm{A})$ vegetated sites and (B) depth integrated sulfate reduction rates (SRR) in vegetated and bare sites in Cymodocea nodosa and Caulerpa prolifera communities. Bars represent mean of 3 replicates $( \pm$ SEM)
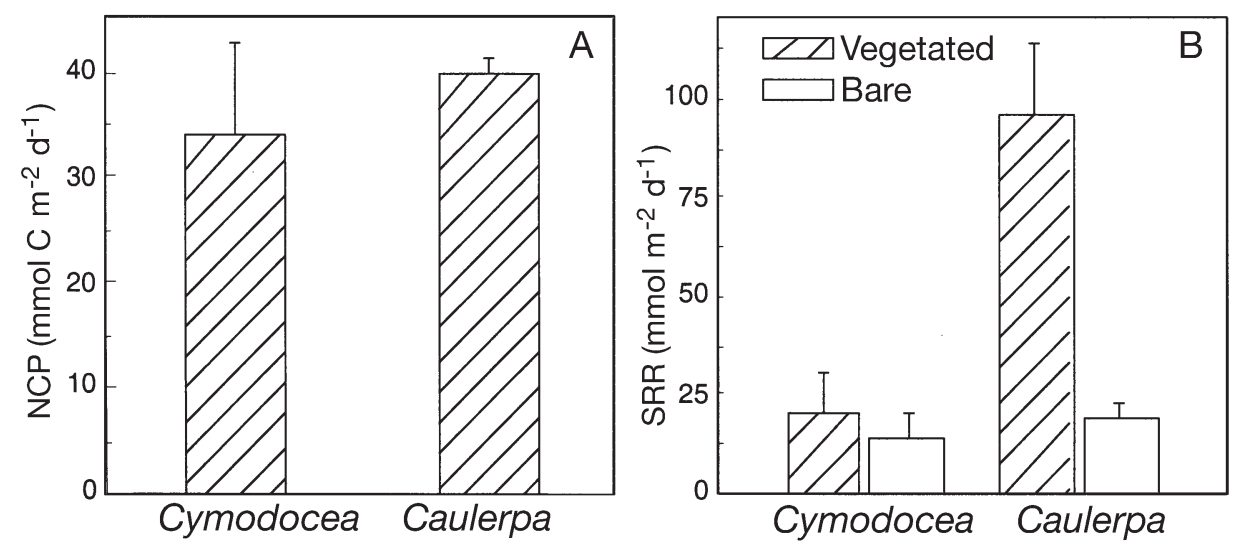
tions (Duarte 1995). At the anthropogenic impacted site Porto Colom, where P. oceanica is declining due to intense nutrient loading caused by urban developments and aquaculture activity (Grau pers. comm.), the bacteria also showed a signal only partially explained by seagrass detritus. Here the isotopic signal of the sediment bacteria was close to that of the material collected by the sediment traps, suggesting that seston inputs were the dominant source of carbon for bacteria.

The sediment bacteria at the Cymodocea nodosa site showed a mixed signal in between the seagrass signal and the seston, suggesting that both sources are important microbial substrates. C. nodosa had a more depleted isotopic signal than Posidonia oceanica, highlighting the large difference in ratios between seagrass species (Hemminga \& Mateo 1996, Boschker et al. 2000, Boyce et al. 2001). C. nodosa is a much smaller seagrass, with above-ground biomass representing only $1 / 10$ of that for $P$. oceanica; however, it has a high turnover and is able to colonize large areas rapidly, e.g. during the seasonal growth cycle (Marbá \& Duarte 2001). The isotopic signal of the macroalgae Caulerpa prolifera was enriched compared to C. nodosa and close to the signal for $P$. oceanica. At the $C$. prolifera site, the sediment and bacterial isotopic ratios were similar to those for the macroalgae, suggesting that the macroalgae was an important carbon source in the sediments and for the bacteria. C. prolifera is a fastgrowing macroalgae, which has spread in this area during the past decades due to increased nutrient loading of the bay (Grau pers. comm.). C. prolifera is attached to the sediment by small root-like structures, and the closely related C. taxifolia has been found to stimulate microbial activity in the sediments by release of photosynthetic products to the rhizosphere (Chisholm \& Moulin 2003). Mineralization activity was high in both $C$. nodosa and C. prolifera sediments, being 20 to 140 times higher than the pristine P. oceanica sediments. In particular, the $C$. prolifera sediments showed enhanced rates similar to findings in organic enriched fish farm sediments (Holmer \& Kristensen 1996, Holmer et al. 2003b), suggesting that the detritus they produce is of high quality and easily degradable by the sediment bacteria. There was an accumulation of sulfides at both sites, particularly in the C. nodosa sediments, which may be a potential reason for the historic decline in $P$. oceanica distribution at this location (Marbá et al. 2002).

The bare sites deviated from the adjacent vegetated sites by having lower sediment organic contents. Remarkably, however, the isotopic signal of the bacteria was quite uniform and similar to those of nearby seagrasses, suggesting that, as in the adjacent vegetated areas, seagrass detritus was the most important source of organic matter for bacteria. The bare sites were located close to or in the meadows, and a close coupling between the seagrass meadows and the bare sites was thus expected, particularly due to the low organic content of the bare sediments, which should enhance the dependence of bacteria on the imports of seagrass detritus from the adjacent meadows. At Sa Paret, the bare site appeared to be similar to the pristine sites with a stable carbon-isotopic signal in the bacteria similar to the seagrass material. No macroalgae were found at the bare site, and the sediment was coarse in contrast to the muddy conditions found inside the meadow (Table 4), suggesting that only the meadow was affected by the anthropogenic activities, possibly because of the efficient trapping of seston by the seagrass canopy. In Porto Colom, the signal in the bacteria on bare sediments was shifted towards the sediment pools and the sedimentation traps, suggesting a partial utilization of seagrass material and some influence by enhanced sedimentation of seston in this area. Mineralization was also enhanced, with rates similar to the vegetated site.

Knowledge of the stable carbon-isotope composition of the seagrasses, macroalgae and sedimentation and the sediment organic matter allows the fractional contribution from either vegetation or seston to the sediment organic matter at the examined sites to be assessed. The contribution of the different carbon sources was calculated based on a mixing model with seagrasses/macroalgae and material collected in sediment traps as end members (Gacia et al. 2002). Briefly, we used a standard 2-component isotope mixing equation of the form:

$$
\delta^{13} \mathrm{C}_{\text {sed }}=\delta^{13} \mathrm{C}_{\text {vegetation }} f+\delta^{13} \mathrm{C}_{\text {traps }}(1-f)
$$

where $f$ is the fraction derived from the seagrasses/macroalgae. The contribution of seagrass detritus to the sediment organic carbon was highly variable, ranging from very low values (0 to $3 \%$ ) to $69 \%$ with no clear difference between pristine and impacted sediments or between exposed and sheltered sites; this suggests that the burial of detritus is related to other factors, e.g. below-ground production or bioturbation by meio- or macrofauna (Table 5). Similarly, the contribution of seagrass and seston to the bacterial organic carbon sources was calculated using the mixing equation by exchanging $\delta^{13} \mathrm{C}_{\text {sed }}$ with $\delta^{13} \mathrm{C}_{\mathrm{bac}}$. Here there were some general trends, with a high contribution ( $>91 \%$ ) to the bacterial carbon at the pristine Posidonia oceanica sites, whereas the contribution of seagrass and sediment trap material was more similar at the anthropogenic impacted sites (Table 5). The macroalgae Caulerpa prolifera could account for all the carbon used by sediment bacteria at the C. prolifera site, whereas $58 \%$ of the organic carbon in the 
Table 5. Contribution of seagrass (Posidonia oceanica and Cymodocea nodosa sites) or macroalgal (Caulerpa prolifera site) material (plant) to carbon sources in sediment (Sed POC) and bacteria (Bac POC) based on a mixing model between 2 carbon sources (seagrass/macroalgal and sediment trap material, see text for further explanation). A value $>100$ indicates that the isotopic value of either sediment or bacteria was more depleted than the seagrass or macroalgal signal

\begin{tabular}{|lccc|}
\hline Location & Veg/bare & $\begin{array}{c}\text { \%plant in } \\
\text { Sed POC }\end{array}$ & $\begin{array}{c}\text { \%plant in } \\
\text { Bac POC }\end{array}$ \\
\hline Magalluf & Posidonia oceanica & 0 & 100 \\
Sta. Maria & Bare & 0 & 91 \\
& Posidonia oceanica & 68 & $>100$ \\
Sa Paret & Bare & 69 & $>100$ \\
Porto Colom 1 & Posidonia oceanica & 62 & 51 \\
Porto Colom 2 & Bare & 49 & 98 \\
& Caulerpa prolifera & 0 & 51 \\
Es Port & Bare & 3 & 76 \\
& Cymodocea nodosa & 5 & $>100$ \\
& Bare & 46 & 76 \\
& & & 58 \\
\hline
\end{tabular}

inside $P$. oceanica meadows suggest a significant release of DOC from the community (Velimirov 1986). P. oceanica show similar functionality to other seagrasses, and transport and accumulate carbon compounds in below-ground structures (Alcoverro et al. 2001); however, their roots are quite rigid with few root hairs (Duarte et al. 1998), indicating that the release of organic compounds may be limited. The leaves and belowground tissues of $P$. oceanica are considered to be more refractory compared to other fastgrowing seagrasses, and detritus accumulates as a result of the slow mineralization which leads to the characteristic 'matte' formation (Hemminga \& Duarte 2000, Gacia et al. 2002).

The results presented here confirm the importance of seagrasses as a carbon substrate to maintain the enhanced bacterial activity often associated to seagrass sediments (Holmer \& Nielsen 1997, Hemminga \& Duarte 2000, Holmer et al. 2001). The impor-

sediment bacteria in the Cymodocea nodosa meadow was derived directly from the seagrass.

The data presented provide evidence of an organic enrichment at the impacted stations, which show levels of sediment organic carbon up to 11-fold greater than the pristine stations, as well as enhanced nitrogen contents in plant tissues. Both impacted sites were located in sheltered bays, which further increase the sedimentation compared to the pristine sites. The SRR were enhanced and contributed 30 to $46 \%$ of R compared to only 6 to $11 \%$ at the pristine sites. Root anoxia and the presence of toxic sulfides have been suggested to impoverish seagrass growth conditions (Terrados et al. 1999), and a special concern in these carbonate sediments with low iron pools is the almost irreversible binding of iron with sulfides which may lead to iron deficiency in the seagrasses (Duarte et al. 1995, Holmer et al. in press). This has been confirmed by an experiment performed at Sa Paret, where additions of iron to the sediments increased seagrass growth by stimulating the activity of enzymes catalyzing nutrient uptake (Holmer et al. in press). All communities examined where autotrophic, and the NCP was significantly higher at the most pristine site (Sta. Maria), where the water transparency was high and nutrient concentrations in the water column were low (Marbá et al. 2002), allowing the development of a lush seagrass meadow. A potential release of root exudates is expected to correlate with $\mathrm{NCP}$, but very little is known about the below-ground parts of Posidonia oceanica and whether P. oceanica excretes dissolved organic compounds. Increased concentrations of DOC tance of seagrasses as a carbon source for bacteria cannot be explained by the high production of seagrasses alone, as our calculations of the relative importance of different carbon sources provide strong evidence that sediment bacteria show a higher use of seagrass carbon than expected from its contribution to the sediment organic pool. This finding, which is consistent with previous reports for other oligotrophic seagrass ecosystems (Holmer et al. 2001, Jones et al. 2003), challenges the notion that seagrass detritus is refractory when compared to sestonic carbon. It is possible that the large production of relatively refractory detritus by seagrasses masks the production of more labile compounds readily used by bacteria that account for the enhanced bacterial activity within seagrass sediments. The shift in the relative contribution of carbon sources for the sediment bacteria from seagrass detritus to external sources (phytoplankton, macroalgae, seston) in organic and nutrient enriched Posidonia oceanica meadows in the Mediterranean clearly shows that external sources are easily decomposed. Mineralization rates increase as the NCP decreases, and the community thus becomes more dominated by heterotrophic processes, as evidenced by a shift towards anaerobic sulfate reduction as a terminal mineralization process.

Acknowledgements. This research was funded by projects EVK3-CT-2000-00044，Q5RS-2001-02456 and 2000/NAT/E/ 7303 of the European Commission and project REN200200701 of the Spanish Plan Nacional de I+D. M.H. was supported by SNF grant no. 21-02-0463. C.B. was supported by a scholarship from the government of the Balearic Island. 
We thank the authorities and officials of the Cabrera Island National Park for their collaboration, and E. Díaz, N. Marbá, R. Martínez, and S. Sørensen for their assistance.

\section{LITERATURE CITED}

Agawin NSR, Duarte CM (2002) Evidence of direct particle trapping by a tropical seagrass meadow. Estuaries 25: 1205-1209

Alcoverro T, Manzanera M, Romero J (2001) Annual metabolic carbon balance of the seagrass Posidonia oceanica: the importance of carbohydrate reserves. Mar Ecol Prog Ser 211:105-116

Bethoux JP, Copin-Móntegu G (1986) Biological fixation of atmospheric nitrogen in the Mediterranean Sea. Limnol Oceanogr 31:1353-1358

Blaabjerg V, Finster K (1998) Sulphate reduction associated with roots and rhizomes of the marine macrophyte Zostera marina. Aquat Microb Ecol 15:311-314

Blomqvist S, Håkanson L (1981) A review on sediment traps in aquatic environments. Arch Hydrobiol 91:101-132

Boschker HTS, Middelburg JJ (2002) Stable isotopes and biomarkers in microbial ecology. FEMS Microbiol Ecol 40: 85-95

Boschker HTS, Nold SC, Wellsbury P, Bos D, De Graaf W, Pel R, Parkes RJ, Cappenberg TE (1998) Direct linking of microbial populations to specific biogeochemical processes by ${ }^{13} \mathrm{C}$-labelling of biomarkers. Nature 392: 801-805

Boschker HTS, De Brouwer JFC, Cappenberg TE (1999) The contribution of macrophyte-derived organic matter to microbial biomass in salt-marsh sediments: Stable carbon isotope analysis of microbial biomarkers. Limnol Oceanogr 44:309-319

Boschker HTS, Wielemaker A, Schaub BEM, Holmer M (2000) Limited coupling of macrophyte production and bacterial carbon cycling in the sediments of Zostera spp. meadows. Mar Ecol Prog Ser 203:181-189

Bower CE, Holm-Hansen T (1980) A salicylate-hypochlorite method for determining ammonia in seawater. Can J Fish Aquat Sci 37:794-798

Boyce MC, Lavery P, Bennett IJ, Horwitz P (2001) Spatial variation in the $\delta^{13} \mathrm{C}$ signature of Ruppia megacarpa (Mason) in coastal lagoons of southwestern Australia and its implication for isotopic studies. Aquat Bot 71:83-92

Chisholm JRM, Moulin P (2003) Stimulation of nitrogen fixation in refractory organic sediments by Cauperla taxifolia (Chlorophyta). Limnol Oceanogr 48:787-794

Cline JD (1969) Spectrophotometric determination of hydrogen sulfide in natural waters. Limnol Oceanogr 14: 454-459

Dauby P, Bale AJ, Bloomer N, Canon C and 7 others (1995) Particle fluxes over a Mediterranean seagrass bed: a one year case study. Mar Ecol Prog Ser 126:233-246

Delgado O, Grau A, Pou S, Riera F, Massuti C, Zabala M, Ballesteros E (1997) Seagrass regression caused by fish cultures in Fornells Bay (Menorca, Western Mediterranean). Oceanol Acta 20:557-563

Duarte CM (1995) Submerged aquatic vegetation in relation to different nutrient regimes. Ophelia 41:87-112

Duarte CM, Cebrián J (1996) The fate of marine autotrophic production. Limnol Oceanogr 41:1758-1766

Duarte CM, Merino M, Gallegos, M (1995) Evidence of iron deficiency in seagrasses growing above carbonate sediments. Limnol Oceanogr 40:1153-1158

Duarte CM, Merino M, Agawin NSR, Uri J, Fortes MD, Galle- gos ME, Marbá N, Hemminga M (1998) Root production and belowground seagrass biomass. Mar Ecol Prog Ser 171:97-108

Faganeli J, Pezdic J, Ogorelec B, Misic M, Najdek M (1994) The origin of sedimentary organic matter in the Adriatic. Cont Shelf Res 14:365-384

Findlay RH, King GM, Watling L (1989) Efficiency of phospholipids analysis in determining microbial biomass in sediments. Appl Environ Microbiol 55:2888-2893

Fossing H, Jørgensen BB (1989) Measurement of bacterial sulfate reduction in sediments: evaluation of a single-step chromium reduction method. Biogeochemistry 8:205-222

Fry B, Sherr EB (1984) Delta C-13 measurements as indicators of carbon flow in marine and fresh-water ecosystems. Contrib Mar Sci 27:13-47

Gacia E, Duarte CM (2001) Elucidating sediment retention by seagrasses: sediment deposition and resuspension in a Mediterranean (Posidonia oceanica) meadow. Estuar Coast Shelf Sci 52:505-514

Gacia E, Duarte CM, Granata T (1999) An approach to the measurement of particle flux and sediment retention within seagrass (Posidonia oceanica) meadows. Aquat Bot 65:255-268

Gacia E, Duarte CM, Middelburg JJ (2002) Carbon and nutrient deposition in a Mediterranean seagrass (Posidonia oceanica) meadow. Limnol Oceanogr 47:23-32

Goodman JL, Moore KA, Dennison WC (1995) Photosynthetic responses of eelgrass (Zostera marina L.) to light and sediment sulfide in a shallow barrier island lagoon. Aquat Bot 50:37-47

Gras AF, Koch MS, Madden CJ (2003) Phosphorus uptake kinetics of a dominant tropical seagrass Thalassia testudinum. Aquat Bot 76:299-315

Hansen HP, Koroleff F (1999) Determination of nutrients. In: Grasshoff K, Kremling K, Ehrhardt M (eds) Methods of seawater analysis. Wiley-VCH Verlag, Weinheim, p 170-174

Hansen K, Kristensen E (1998) The impact of the polychaete Nereis diversicolor and enrichment with macroalgal (Chaetomorpha linum) detritus on benthic metabolism and nutrient dynamics in organic-poor and organic-rich sediment. J Exp Mar Biol Ecol 231:201-223

Hargrave BT, Burns NM (1979) Assessment of sediment trap collection efficiency. Limnol Oceanogr 24:1124-1136

Hartnett HE, Keil RG, Hedges JI, Devol AH (1998) Influence of oxygen exposure time on organic carbon preservation in continental margin sediments. Nature 391:572-572

Harvey HR, Tuttle JH, Bell JT (1995) Kinetics of phytoplankton decay during simulated sedimentation: changes in biochemical composition and microbial activity under oxic and anoxic conditions. Geochim Cosmochim Acta 59: $3367-3377$

Hedges JI (1992) Global biogeochemical cycles: progress and problems. Mar Chem 39:67-93

Hemminga MA, Duarte CM (2000) Seagrass ecology. Cambridge University Press, Cambridge

Hemminga MA, Mateo MA (1996) Stable carbon isotopes in seagrasses: variability in ratios and use in ecological studies. Mar Ecol Prog Ser 140:285-298

Holmer M, Bondgaard EJ (2001) Photosynthetic and growth response of eelgrass to low oxygen and high sulphide concentrations during hypoxic events. Aquat Bot 70:29-38

Holmer M, Kristensen E (1996) Seasonality of sulphate reduction and pore water solutes in a marine fish farm sediment: the importance of temperature and sedimentary organic matter. Biogeochemistry 32:15-39

Holmer M, Nielsen SL (1997) Sediment sulfur dynamics 
related to biomass-density pattern in Zostera marina (eelgrass) beds. Mar Ecol Prog Ser 146:163-171

Holmer M, Andersen FØ, Nielsen SL, Boschker HTS (2001) The importance of mineralization based on sulphate reduction for nutrient regeneration in tropical seagrass sediments. Aquat Bot 71:1-17

Holmer M, Marbà N, Terrados J, Duarte CM, Fortes MD (2002) Impacts of milkfish (Chanos chanos) aquaculture on carbon and nutrient fluxes in the Bolinao area, Philippines. Mar Pollut Bull 44:685-696

Holmer M, Duarte CM, Marbà N (2003a) Sulfur cycling and seagrass (Posidonia oceanica) status in carbonate sediments. Biogeochemistry 66:223-239

Holmer M, Pérez M, Duarte CM (2003b) Benthic primary producers - a neglected environmental problem in Mediterranean maricultures? Mar Pollut Bull 46:1372-1376

Holmer M, Duarte CM, Marbà N (in press) Iron additions improve seagrass growth on impacted carbonate sediments. Ecosystems

Jones WB, Cifuentes LA, Kaldy JE (2003) Stable carbon isotope evidence for coupling between sedimentary bacteria and seagrasses in a sub-tropical lagoon. Mar Ecol Prog Ser 255:15-25

Koroleff F (1983) Determination of nutrients. In: Grasshof K, Ehrhardt M, Kremling K (eds) Methods of seawater analysis. Verlag Chemie, Weinheim, p 125-139

Kristensen E, Holmer M (2001) Decomposition of plant materials in marine sediment exposed to different electron accepters $\left(\mathrm{O}_{2}, \mathrm{NO}_{3}^{-}\right.$and $\left.\mathrm{SO}_{4}{ }^{2-}\right)$, with emphasis on substrate origin, degradation kinetics, and the role of bioturbation. Geochim Cosmochim Acta 65:419-433

Marbà N, Duarte CM (2001) Growth and sediment space occupation by seagrass Cymodocea nodosa roots. Mar Ecol Prog Ser 224:291-298

Marbà N, Duarte CM, Cebrián J, Gallegos ME, Olesen B, Sand-Jensen K (1996) Growth and population dynamics of Posidonia oceanica on the Spanish Mediterranean coast:

Editorial responsibility: Fereidoun Rassoulzadegan, Villefranche-sur-Mer, France elucidating seagrass decline. Mar Ecol Prog Ser 137: 203-213

Marbà N, Duarte CM, Holmer M, Martínez R, Basterretxea G, Orfila A, Jordi A, Tintoré J (2002) Effectiveness of protection of seagrass (Posidonia oceanica) populations in the Cabrera National Park (Spain). Environ Conserv 29: $509-518$

Middelburg JJ, Nieuwenhuize J (1998) Carbon and nitrogen stable isotopes in suspended matter and sediments from the Schelde Estuary. Mar Chem 60:217-225

Middelburg JJ, Barranguet C, Boschker HTS, Herman PMJ, Moens T, Heip CHR (2000) The fate of intertidal microphytobenthos carbon: an in situ C-13-labeling study. Limnol Oceanogr 45:1224-1234

Nieuwenhuize J, Maas YEM, Middelburg JJ (1994) Rapid analysis of organic carbon and nitrogen in particulate materials. Mar Chem 45:217-224

Pedersen AGU, Berntsen J, Lomstein Baa (1999) The effect of eelgrass decomposition on sediment carbon and nitrogen cycling: a controlled laboratory experiment. Limnol Oceanogr 44:1978-1992

Ruiz JM, Pérez M, Romero J (2001) Effects of fish farm loadings on seagrass (Posidonia oceanica) distribution, growth and photosynthesis. Mar Pollut Bull 42:749-760

Terrados J, Duarte CM, Kamp-Nielsen L, Borum J and 6 others (1999) Are seagrass growth and survival affected by reducing conditions in the sediment? Aquat Bot 65: 175-197

Valiela I, Collins G, Kremer J, Lathja K, Geist M, Seely B, Brawley J, Sham CH (1997) Nitrogen loading from coastal watersheds to receiving estuaries: new method and application. Ecol Appl 7:358-380

van Katwijk MM, Vergeer LHT, Schmitz GHW, Roelofs JGM (1997) Ammonium toxicity in eelgrass Zostera marina. Mar Ecol Prog Ser 157:159-173

Velimirov B (1986) DOC dynamics in a Mediterranean seagrass system. Mar Ecol Prog Ser 28:21-41

Submitted: February 5, 2004; Accepted: May 24, 2004

Proofs received from author(s): July 28, 2004 